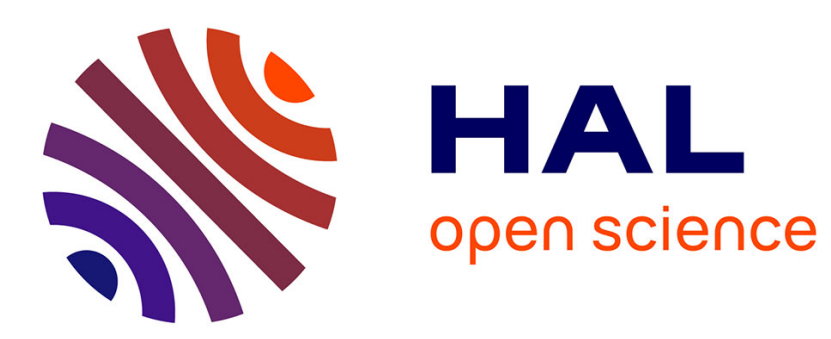

\title{
Autolysis and related proteolysis in Swiss cheese for two Lactobacillus helveticus strains
}

Florence Valence, Stéphanie-Marie Deutsch, R. Richoux, Valérie Gagnaire, Sylvie S. Lortal

\section{> To cite this version:}

Florence Valence, Stéphanie-Marie Deutsch, R. Richoux, Valérie Gagnaire, Sylvie S. Lortal. Autolysis and related proteolysis in Swiss cheese for two Lactobacillus helveticus strains. Journal of Dairy Research, 2000,67, pp.261-271. hal-02694674

\section{HAL Id: hal-02694674 \\ https://hal.inrae.fr/hal-02694674}

Submitted on 1 Jun 2020

HAL is a multi-disciplinary open access archive for the deposit and dissemination of scientific research documents, whether they are published or not. The documents may come from teaching and research institutions in France or abroad, or from public or private research centers.
L'archive ouverte pluridisciplinaire HAL, est destinée au dépôt et à la diffusion de documents scientifiques de niveau recherche, publiés ou non, émanant des établissements d'enseignement et de recherche français ou étrangers, des laboratoires publics ou privés. 


\title{
Autolysis and related proteolysis in Swiss cheese for two Lactobacillus helveticus strains
}

\author{
BY FLORENCE VALENCE, STÉPHANIE-MARIE DEUTSCH, \\ ROMAIN RICHOUX*, VALÉRIE GAGNAIRE AND SYLVIE LORTAL $\dagger$ \\ Institut National de la Recherche Agronomique, Laboratoire de Recherche de \\ Technologie Laitière, 65 rue de Saint-Brieuc, F-35042 Rennes Cédex, France \\ * Institut Technique Français des Fromages, BP 6224, \\ F-35062 Rennes Cédex, France
}

(Received 18 January 1999 and accepted for publication 4 October 1999)

Summary. Intracellular peptidases of Lactobacillus helveticus may play a major role in the proteolysis of Swiss cheeses, provided that they are released through bacterial lysis. Experimental Swiss cheeses were manufactured on a small scale from thermized and microfiltered milk using as starters (in addition to Streptococcus thermophilus and Propionibacterium freudenreichii) one of two Lb. helveticus strains, ITGLH1 and ITGLH77, which undergo lysis to different extents in vitro. All the cheeses were biochemically identical after pressing. The viability of $L b$. helveticus ITGLH1 and ITGLH77 decreased to a similar extent (96-98\%) while in the cold room, but the concomitant release of intracellular lactate dehydrogenase in cheeses made with strain ITGLH1 was 5-7-fold that in cheeses made with ITGLH77. Protein profiles and immunoblot detection of the dipeptidase PepD confirmed a greater degree of lysis of the ITGLH1 strain. Free active peptidases were detected in aqueous extracts of cheese for both strains, and proteolysis occurred principally in the warm room. Reversed-phase HPLC revealed a more extensive peptide hydrolysis for ITGLH1, which was confirmed by the greater release of free $\mathrm{NH}_{2}$ groups $(+33 \%)$ and free amino acids $(+75 \%)$ compared with ITGLH77. As the intracellular peptidase activities of ITGLH1 and ITGLH77 have previously been shown to be similar, our results indicated that the extent of lysis of $L b$. helveticus could have a direct impact on the degree of proteolysis in Swiss cheeses.

Autolysis of starters is now regarded as a necessary part of cheese ripening, allowing cytoplasmic peptidases to be released into the curd to participate actively in further proteolysis (Crow et al. 1993, 1995a). Autolysis of Lactococcus lactis has been clearly established in semi-hard cheeses such as Cheddar and Saint-Paulin (Chapot-Chartier et al. 1994; Wilkinson et al. 1994a,b) and the extent of lysis was shown to be strain dependent and to have a positive influence on secondary proteolysis (O'Donovan et al. 1996). The relationship between lysis of the lactococei and the extent of proteolysis was further demonstrated by provoking various levels of autolysis of the same strain, either by adding small quantities of phages (Crow et al. 1995b) or by using a lytic bacteriocin (Fox \& McSweeney, 1996).

Less information is available on the autolysis of thermophilic lactobacilli (Lortal et al. 1997). Lactobacillus helveticus is an essential species in Swiss cheesemaking and

$\dagger$ For correspondence. 
its intracellular peptidases were estimated to be particularly effective compared with those of other lactic acid bacteria (El Soda et al. 1991). Its autolysis was studied in buffered solutions or 'cheese-like' media (Ohmiya \& Sato, 1970; Bie \& Söjström, 1975) and a preliminary characterization conducted of the autolysins involved (Lortal et al. 1991; Valence \& Lortal, 1995). However, the autolysis of Lb. helveticus was only recently demonstrated in experimental and commercial Swiss cheeses using a species-specific lysis marker, the dipeptidase PepD (Valence et al. 1998).

In the present study, a new series of Swiss cheese experiments was undertaken with two industrial strains of Lb. helveticus, ITGLH77 and ITGLH1, in order to confirm the early autolysis of Lb. helveticus, to compare its extent for two different strains and to assess its impact on the secondary proteolysis. Moreover, as salt is often cited as a potential lysis inducer (Vegarud et al. 1983; Yabu \& Kaneda, 1995) some experimental cheese assays were conducted without brining.

MATERIALS AND METHODS

Organisms and culture conditions

Lb. helveticus ITGLH77 (LH77) and ITGLH1 (LH1) and Propionibacterium freudenreichii ITGP23 (P23) were commercial starters from the Institut Technique Français des Fromages (ITFF, formerly Institut Technique du Gruyère) collection (F-35062 Rennes, France). Streptococcus thermophilus was a direct-to-vat commercial starter (TA060) from Texel (F-86220 Dangé Saint-Romain, France). The $L b$. helveticus strains were selected for their different autolysis efficiency in vitro according to laboratory screening (Lortal et al. 1997). The extent of autolysis in $0 \cdot 1$ M-potassium phosphate buffer, $\mathrm{pH} 5 \cdot 8$ after $16 \mathrm{~h}$ at $40{ }^{\circ} \mathrm{C}$ for LH77 and LH1 was 62 and $34 \%$ respectively. Lb. helveticus was stored in MRS broth (Difco, Detroit, MI 48232, USA) and Prop. freudenreichii strains in yeast extract-lactate broth (Malik et al. 1968), both at $-80^{\circ} \mathrm{C}$. The media were supplemented with $150 \mathrm{ml}$ glycerol/l prior to freezing. For propagating the strains, the respective media without glycerol were used and growth was monitored by measuring $A_{650}$.

For cheese trials, cultures were revived from frozen stocks, first by a transfer in reconstituted milk (100 g lait G/l; Standa Industrie, F-14050 Caen, France) at $2 \mathrm{ml}$ inoculum/l until lactic acid reached $7.5 \mathrm{~g} / \mathrm{l}$ as measured by Dornic acidity, followed by a second transfer on Phagex commercial medium (Standa Industrie) at $100 \mathrm{ml}$ inoculum/l until lactic acid reached $9 \cdot 5 \mathrm{~g} / \mathrm{l}$ for Lb. helveticus, or by two consecutive transfers in yeast extract-lactate broth at $20 \mathrm{ml}$ inoculum/l until $A_{650}$ reached 1 for Prop. freudenreichii.

Preparation of crude cytoplasm

Cells were harvested by centrifugation $(7000 \mathrm{~g}, 20 \mathrm{~min})$ at the beginning of the exponential growth phase and washed twice in cold sterile distilled water. The pellet was stored at $-18{ }^{\circ} \mathrm{C}$ for $24 \mathrm{~h}$ before being resuspended in a volume of cold sterile distilled water $1 / 15$ th of the initial volume of the culture and then subjected to treatment in a French Press apparatus at $4{ }^{\circ} \mathrm{C}$ and $138 \mathrm{MPa}$ for $5 \mathrm{~min}$ (one run). The suspension was centrifuged at $40000 \mathrm{~g}$ and $4{ }^{\circ} \mathrm{C}$ to eliminate unbroken cells and cell walls. The supernatant represented crude cytoplasm and was stored at $-18^{\circ} \mathrm{C}$. Protein content was assayed by the micro-procedure of Bradford (Bio-Rad, F-94203 Ivry-sur-Seine, France) using bovine serum albumin (Sigma, F38297 Saint-Quentin Fallavier, France) as standard. 
Cheese manufacture

Small scale experimental Swiss cheeses were made from $10.3 \mathrm{~kg}$ thermized and microfiltered milk as described by Valence et al. (1998) with a starter comprising Str. thermophilus TA060, Prop. freudenreichii P23 and Lb. helveticus LH1 or LH77. Three cheeses were made in parallel from the same batch of milk, one with $L b$. helveticus LH1 (LH1 cheese), one with LH77 (LH77 cheese) strain and one with LH77 but without brining. Samples were taken just after pressing (day 0 ), in the middle (day 16 ) and at the end (day 27) of the period in the cold room, at the middle (day 44) and the end (day 69) of warm room treatment and after $25 \mathrm{~d}$ cold storage (day 96).

Chemical analysis of cheeses

Total solids (International Dairy Federation, 1982), fat (Heiss, 1966) and $\mathrm{NaCl}$ content (International Dairy Federation, 1988) were determined in the ripened cheese on day 69 . Lactate was monitored during ripening using a kit from Boehringer (D-68298 Mannheim 1, Germany).

Starter viability

A $10 \mathrm{~g}$ cheese sample was homogenized in $90 \mathrm{~g}$ trisodium citrate $(20 \mathrm{~g} / \mathrm{l})$ with a Waring Blendor (Prolabo, F-94126 Fontenay-sous-Bois, France) once for $20 \mathrm{~s}$ at maximum speed then twice for $10 \mathrm{~s}$ at minimum speed. The viability of starter lactobacilli in cheese was measured by plating serial dilutions of samples on MRS agar $(\mathrm{pH} 5 \cdot 4)$ and incubating at $37{ }^{\circ} \mathrm{C}$ for $48 \mathrm{~h}$. Prop. freudenreichii cells were enumerated on a selective medium (Pal Propiobac; Standa Industrie) after incubation at $30{ }^{\circ} \mathrm{C}$ for $5 \mathrm{~d}$ and Str. thermophilus cells on M17 agar plate (Biokar 088, F-60000 Beauvais, France) after incubation at $43{ }^{\circ} \mathrm{C}$ for $16 \mathrm{~h}$. Non-starter lactic acid bacteria were enumerated on $\mathrm{FH}$ agar plates (Isolini et al. 1990) after incubation at $37{ }^{\circ} \mathrm{C}$ for $3 \mathrm{~d}$. Anaerobic growth conditions (Anaerocult A; Merck, F-94736 Nogentsur-Marne, France) were used for all species and results were expressed as efu/g cheese.

Aqueous cheese extracts

Aqueous cheese extracts were prepared as described by Valence et al. (1998). Each cheese sample $(20 \mathrm{~g})$ was homogenized with an Ultra-Turrax disperser (Bioblock, F-67403 Illkirch, France) for $2 \mathrm{~min}$ in $80 \mathrm{ml}$ distilled water. The suspension was held at $38^{\circ} \mathrm{C}$ for $20 \mathrm{~min}$ before centrifugation at $3000 \mathrm{~g}$ and $4{ }^{\circ} \mathrm{C}$ for $15 \mathrm{~min}$. After removal of the upper solid fat layer the supernatant was filtered through Whatman no. 1 paper and then a $0.45 \mu \mathrm{m}$ acetate filter (Sartorius, F-91127 Palaiseau, France) and stored at $-18^{\circ} \mathrm{C}$ until used.

Evidence for free active peptidases in aqueous cheese extracts

The aqueous cheese extracts obtained on day 16 were aseptically filtered through a $0.22 \mu \mathrm{m}$ acetate filter (Sartorius) and incubated at $24{ }^{\circ} \mathrm{C}$ to simulate conditions prevailing during the ripening of Emmental in the warm room as described by Gagnaire et al. (1998). Total free $\mathrm{NH}_{2}$ groups resulting from the action of free peptidases on casein peptides were assayed.

SDS-PAGE analysis of total protein content of the aqueous cheese extracts

SDS-PAGE was carried out as described by Valence \& Lortal $(1995)$ at $25^{\circ} \mathrm{C}$ with an SDS polyacrylamide $(140 \mathrm{~g} / \mathrm{l})$ separating gel and a constant voltage of $180 \mathrm{~V}$ for $1 \mathrm{~h}$. Samples were mixed with an equal volume of Laemmli buffer $(62.5 \mathrm{~mm}$-Tris $\mathrm{HCl}$, 
pH 6.8 containing (per l) $100 \mathrm{ml}$ glycerol, $20 \mathrm{~g}$ SDS and $50 \mathrm{ml} 2$-mercaptoethanol) and boiled for 2 min (Laemmli, 1970); $20 \mu \mathrm{l}$ of each sample was loaded on to the gel. Each sample was analysed at least twice.

Autolysis of starters in cheese

Autolysis was monitored during the ripening period by measuring the release of intracellular enzymes into the cheese matrix.

Lactate dehydrogenase. The lactate dehydrogenase (EC 1.1.1.27; LDH) activity was assayed as described by Thomas (1975). Activity was expressed as units of activity $/ \mathrm{ml}$ aqueous cheese extract, where one unit of activity represented the amount of enzyme required for the reduction of $1 \mu \mathrm{mol}$ pyruvate $/ \mathrm{min}$ at $37^{\circ} \mathrm{C}$. Each assay was carried out in triplicate.

Dipeptidase. The $53.5 \mathrm{kDa}$ dipeptidase (PepD) used as a species-specific lysis marker for Lb. helveticus by Valence et al. (1998) was detected by immunoblotting as described previously. Samples of aqueous cheese extracts were subjected to SDSPAGE and then transblotted on to a nitrocellulose sheet $(0.45 \mu \mathrm{m}$ pore size; Millipore, F-78051 Saint-Quentin-en-Yvelines, France).

Extent of proteolysis in cheese

Determination of total free $\mathrm{NH}_{2}$ groups. These were assayed according to the procedure of Church et al. (1985) with methionine (Sigma) as standard. Samples $(75 \mu \mathrm{l})$ were incubated at $25{ }^{\circ} \mathrm{C}$ for 2 min with $1.5 \mathrm{ml} \mathrm{o}$-phthaldialdehyde reagent ( 5 mu-sodium tetraborate- 3.5 mu-SDS- 6 mu-o-phthaldialdehyde containing $2 \mathrm{ml}$ 2-mercaptoethanol/l). Absorbance was monitored at $340 \mathrm{~nm}$ and results expressed as mmol methionine equivalent/l. Each assay was performed in triplicate.

Analysis of free amino acids. Aqueous cheese extracts $(100 \mu \mathrm{l})$ were first treated with $900 \mu \mathrm{l}$ absolute ethanol at $20^{\circ} \mathrm{C}$ at $1 \mathrm{~h}$. The mixtures were centrifuged at $2400 \mathrm{~g}$ for $15 \mathrm{~min}$ and the supernatants $(800 \mu \mathrm{l})$ dried in a Speedvac evaporator and subjected to derivatization with phenyl isothiocyanate (Pierce, Touzart \& Matignon, F-94403 Vitry-sur-Seine, France). The amino acid derivatives were determined in triplicate using reversed-phase HPLC (Picotag $\mathrm{C}_{18}$ column; $150 \times 3.9 \mathrm{~mm}$ i.d; Waters, F-78056 Saint-Quentin-en-Yvelines, France) according to Bidlingmeyer et al. (1984).

Chromatographic analysis. Filtered aqueous cheese extracts were diluted and their $\mathrm{pH}$ adjusted to 2 with trifluoroacetic acid $(100 \mathrm{ml} / \mathrm{l}$; Pierce, Touzart et Matignon). Portions $(100 \mu \mathrm{l})$ were injected on to the analytical reversed-phase column (Lichrosper $100 \mathrm{RP} \mathrm{C}_{18}$ column; $124 \times 4 \mathrm{~mm}$ i.d.; Merck) equilibrated at $40{ }^{\circ} \mathrm{C}$ at a flow rate of $1 \mathrm{ml} / \mathrm{min}$ with buffer A (HPLC grade trifluoroacetic acid (Millipore) in Milli-Q water, $1.06 \mathrm{ml} / \mathrm{l}$ ). Elution was with a linear gradient from 50 to $680 \mathrm{ml} / \mathrm{l}$ of buffer B (1 ml trifluoroacetic acid/l in $800 \mathrm{ml}$ acetonitrile/l Milli-Q water) over 62 min, followed by $680 \mathrm{ml} \mathrm{B} / \mathrm{l}$ to pure B in $2 \mathrm{~min}$. The absorbance was monitored at $214 \mathrm{~nm}$ with a u.v. detector (Spectra Physics SP 8490 ; Thermo Separation Products, F-78030 Les Ulis, France).

\section{Chemical analysis of the cheeses}

RESULTS

These results were similar to those obtained for small scale experimental Swiss cheese by Valence et al. (1998) and were in agreement with previous values obtained for Swiss cheese (Buisson et al. 1987; Steffen et al. 1993). Total solids, moisture in nonfat substance and $\mathrm{pH}$ at moulding were (means $\pm \mathrm{SD}$ ) $585 \pm 2 \mathrm{~g} / \mathrm{kg}, 579 \pm 2 \mathrm{~g} / \mathrm{kg}$ and $6 \cdot 38 \pm 0.02$ respectively. The $\mathrm{pH}$ of the cheese fell to $5 \cdot 20 \pm 0.02$ within the first $24 \mathrm{~h}$. 


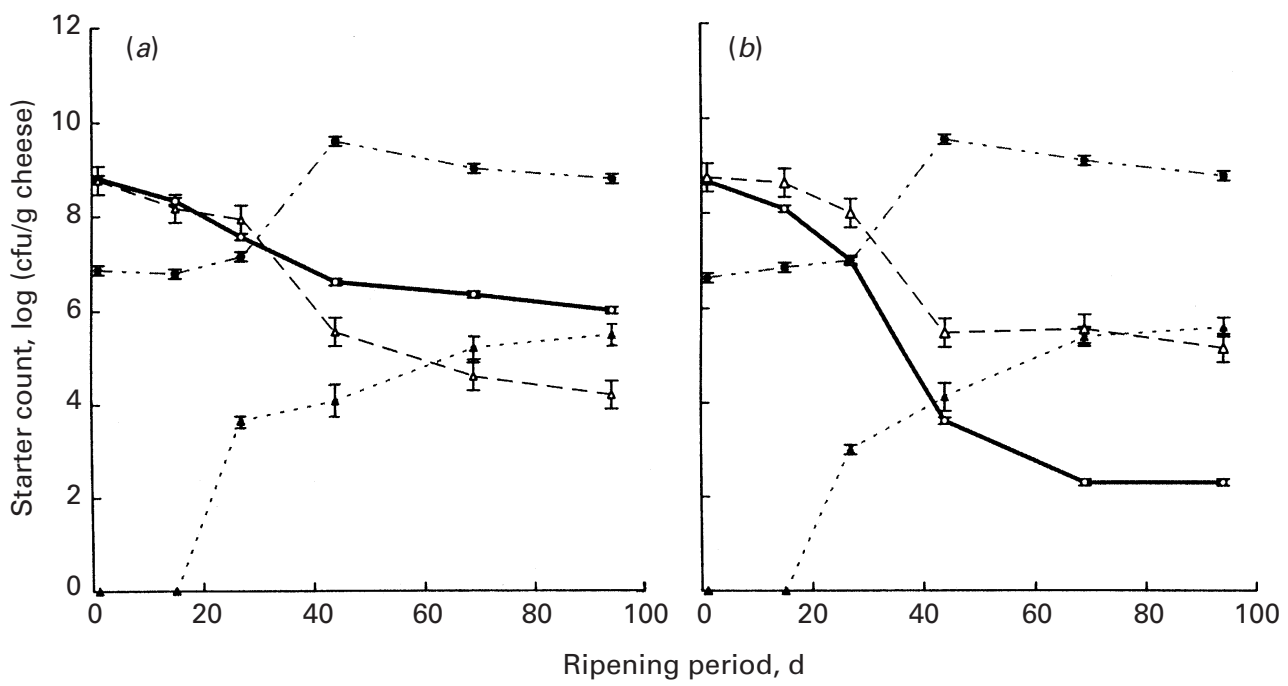

Fig. 1. Counts of starter strains during ripening in experimental cheeses made with (a) Lactobacillus helveticus ITGLH1 and (b) Lb. helveticus ITGLH77 in addition to Streptococcus thermophilus TA060 and Propionibacterium freudenreichii P23. ○, Lb. helveticus;, Propionibacterium freudenreichii; $\triangle$, Streptococcus thermophilus; $\boldsymbol{\Delta}$, non-starter lactic acid bacteria. Values are means from three trials with sD indicated by vertical bars.

Both $L b$. helveticus strains produced similar acidification (results not shown) and lactate contents $(13 \cdot 0 \pm 0 \cdot 1 \mathrm{~g} / \mathrm{kg}$ on day 1$)$. The ripened cheeses had $623 \cdot 5 \pm 2 \cdot 5 \mathrm{~g}$ total solids $/ \mathrm{kg}, 530 \pm 2 \mathrm{~g}$ moisture $/ \mathrm{kg}$ non-fat substance, $464.5 \pm 1.5 \mathrm{~g}$ fat $/ \mathrm{kg}$ dry matter and $9 \cdot 3 \pm 0 \cdot 2 \mathrm{~g}$ salt $/ \mathrm{kg}$ moisture.

\section{Viability of starter and non-starter bacteria during ripening}

The maximal growth of Lb. helveticus and Str. thermophilus $\left(5 \times 10^{8} \mathrm{cfu} / \mathrm{g}\right.$ cheese) was followed by a dramatic decrease in viability during ripening in the cold room: 96 and $98 \%$ for LH1 and LH77 respectively (Fig. 1). At the end of ripening the viable counts of Lb. helveticus were $10^{6}$ and $2 \times 10^{2} \mathrm{cfu} / \mathrm{g}$ cheese for LH1 and LH77 respectively. The viability of Str. thermophilus also fell sharply, at a similar rate for all cheeses. The maximal growth of Prop. freudenreichii was reached in the warm room, followed by a decrease in viability of $85 \%$ (Fig. 1). The non-starter lactic acid bacteria, not detectable at the beginning of the ripening, did not exceed $10^{6} \mathrm{cfu} / \mathrm{g}$ cheese at any time (Fig. 1). Omitting the brining stage had no effect on the changes in viability for any starter strain (results not shown).

\section{Bacterial lysis in cheese}

The LDH activity of aqueous extracts of LH1 and LH77 cheeses increased during ripening in the cold and warm rooms (Fig. 2), with maximal activity being reached at the end of ripening (day 69). For LH1 cheese, LDH activity was already detectable on day 0 ; it then increased faster and was always $5-7$-fold the level found in LH77 cheese. The absence of brining had no effect on the LDH activity (Fig. 2). The intracellular LDH activities for Lb. helveticus LH1 and LH77 and Str. thermophilus TA060 were (units/mg cytoplasmic proteins, means $\pm \mathrm{SD}$ ) $1 \cdot 2 \pm 0 \cdot 2$, $3 \cdot 0 \pm 0 \cdot 2$ and $2 \cdot 9 \pm 0 \cdot 1$ respectively. Prop. freudenreichii exhibited no NAD-dependent LDH activity. As the cheeses were made from microfiltered thermized milk, the LDH detected could only have come from the thermophilic lactic starters, i.e. $L b$. helveticus or Str. thermophilus. 


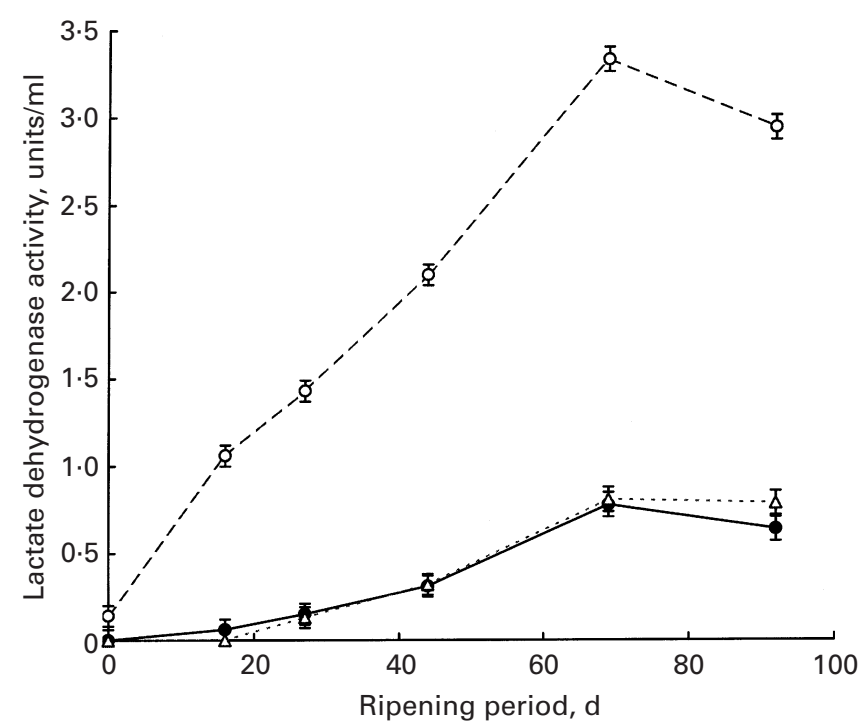

Fig. 2. Lactate dehydrogenase activity in the aqueous extracts from experimental cheeses at different times of ripening. Cheeses were made with (in addition to Streptococcus thermophilus TA060 and Propionibacterium freudenreichii P23) $\bigcirc$, Lactobacillus helveticus ITGLH1;,$\triangle$, Lb. helveticus ITGLH77; brined; $\triangle$, non-brined. Values are means from three trials with SD indicated by vertical bars. (One unit of activity corresponds to the amount of enzyme required for the reduction of $1 \mu \mathrm{mol}$ pyruvate $/ \min$ at $37^{\circ} \mathrm{C}$.)

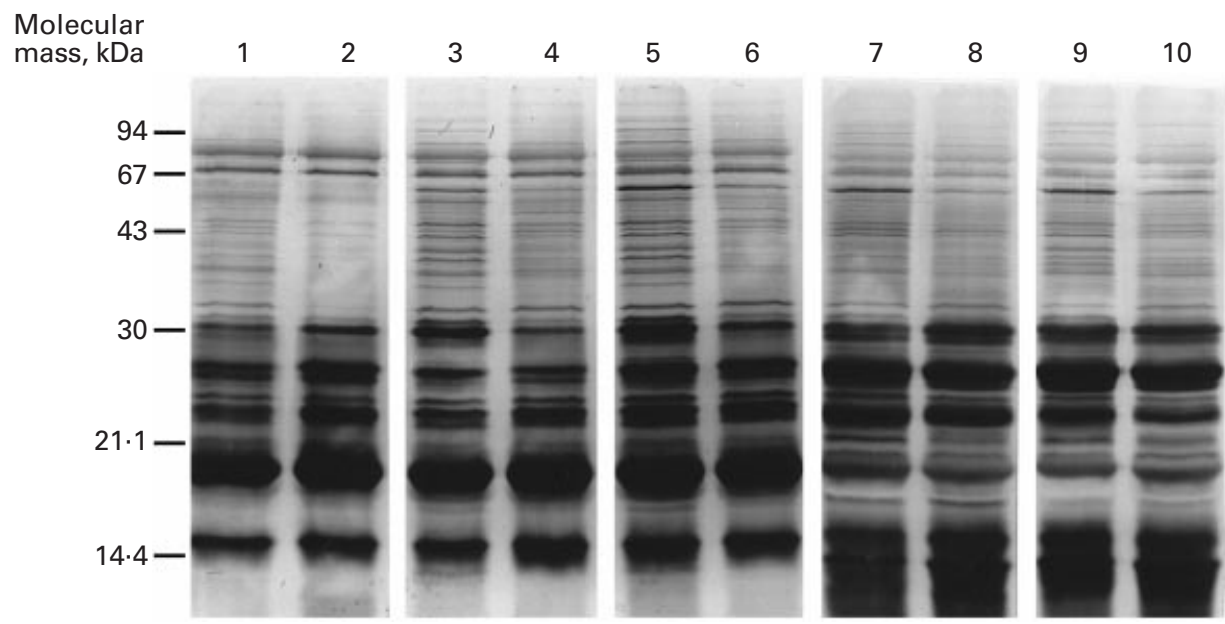

Fig. 3. SDS-PAGE of aqueous extracts of experimental cheeses at different times of ripening showing differences in the protein profiles depending on the Lactobacillus helveticus starter used. The cheeses were made with Lactobacillus helveticus ITGLH1 (lanes 1, 3, 5, 7 and 9) or Lb. helveticus ITGLH77 (lanes 2, 4, 6, 8 and 10) in addition to Streptococcus thermophilus TA060 and Propionibacterium freudenreichii P23. Lanes 1 and 2 , day 1 ; lanes 3 and 4, day 16 ; lanes 5 and 6 , day 27 ; lanes 7 and 8 , day 44 ; lanes 9 and 10, day 69 . Molecular masses of standard proteins are indicated on the left.

As the SDS-PAGE profile of the milk did not contain proteins in the range $30-60 \mathrm{kDa}$, any detected of this size were assumed to come from bacterial starters (Valence et al. 1998). SDS-PAGE of aqueous extracts of LH1 and LH77 cheeses during ripening revealed, for an equal volume loaded per lane, an increase in the intensity and number of protein bands $>30 \mathrm{kDa}$ between days 0 and 16 (Fig. 3). At day 16, the intensity for these proteins for LH1 cheese was 8-10-fold that for LH77 


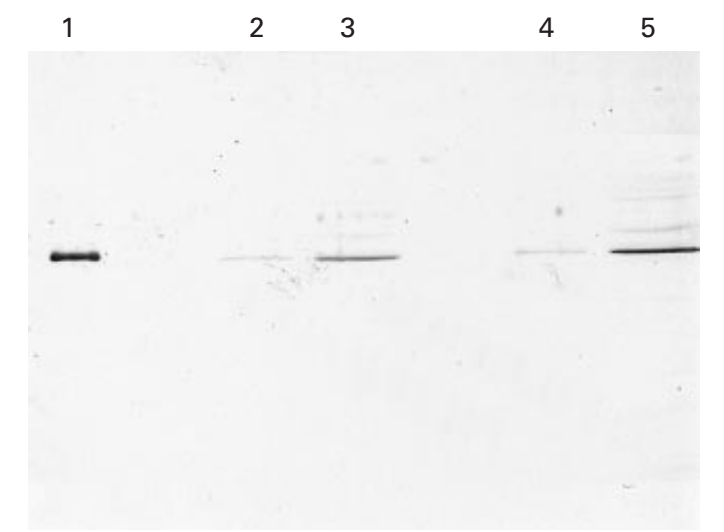

Fig. 4. Immunoblotting with anti-peptidase serum showing the autolysis of Lactobacillus helveticus strains in experimental cheeses at different ripening times. Lane 1, purified PepD (3 ng); cheeses made with (in addition to Streptococcus thermophilus TA060 and Propionibacterium freudenreichii P23) lanes 2 and 3, Lb. helveticus ITGLH77; lanes 4 and 5, Lb. helveticus ITGLH1. Lanes 2 and 4, day 1 ; lanes 3 and 5 , day 27 .

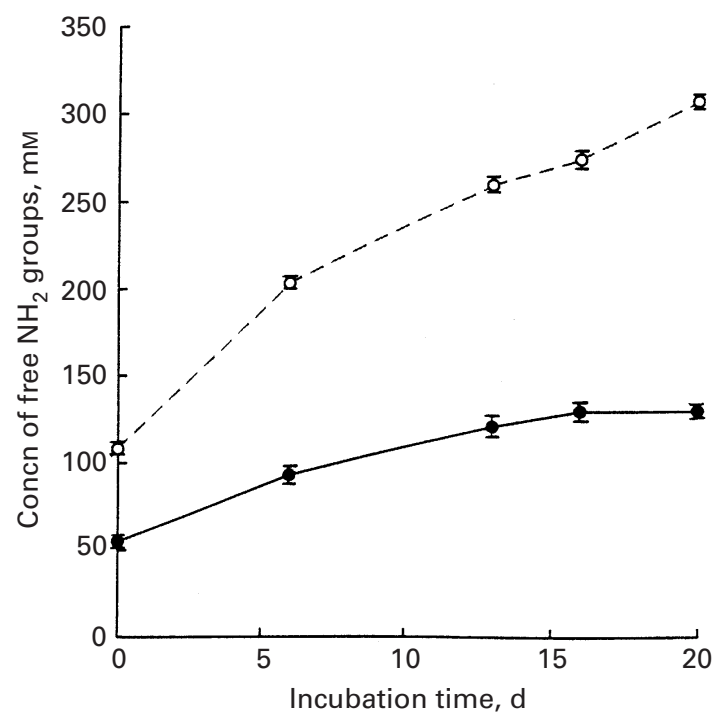

Fig. 5. Release of free amino groups in aqueous extracts of experimental cheeses obtained after $16 \mathrm{~d}$ ripening, sterilized by filtration and incubated statically at $24{ }^{\circ} \mathrm{C}$ for $20 \mathrm{~d}$. Extracts were from cheeses made with (in addition to Streptococcus thermophilus TA060 and Propionibacterium freudenreichii P23) $\bigcirc$, Lactobacillus helveticus ITGLH1;, Lb. helveticus ITGLH77. Values are means from three trials with SD indicated by vertical bars.

cheese. (This was determined by loading increasing quantities of aqueous extracts of LH77 cheese and densitometric analysis; results not shown). The intensity then rose steadily between days 16 and 44 .

A weak band of PepD was detected as early as day 0 ; in the cold room this increased until day 27 (Fig. 4), after which no variation could be detected to the end of ripening (results not shown). The intensity varied with the strain of Lb. helveticus: on day 27 that for LH1 cheese was 3 -fold that for LH77 cheese (results not shown). However, the value for LH1 cheese may have been underestimated owing to saturation of the Western blotting (Valence et al. 1998). 


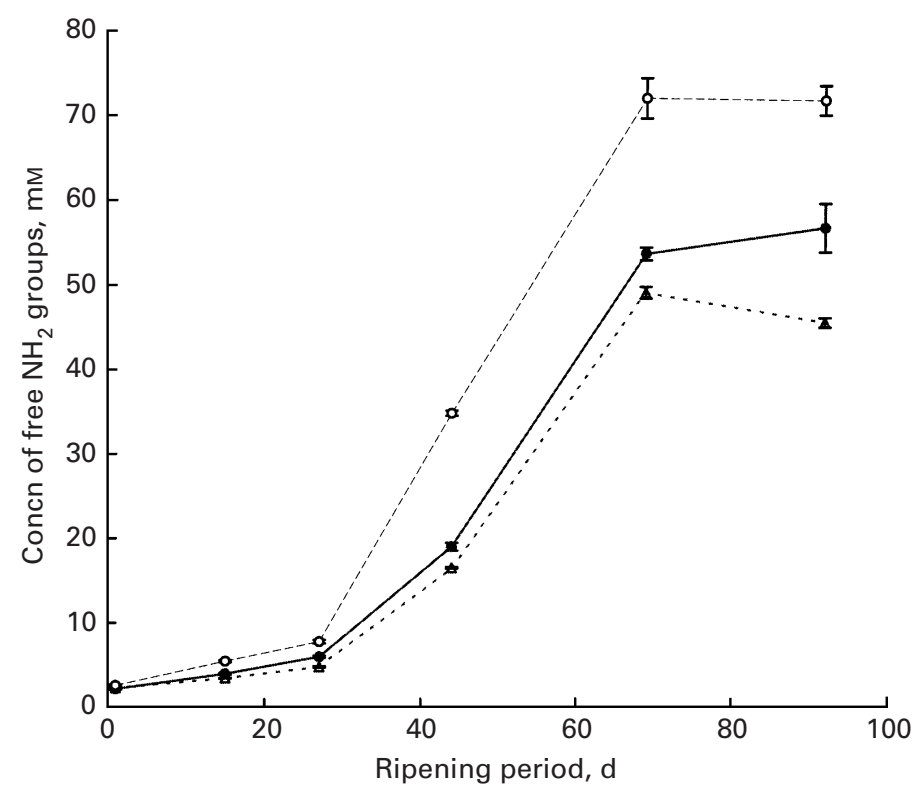

Fig. 6. Formation of free amino groups during the ripening of experimental cheeses made with (in addition to Streptococcus thermophilus TA060 and Propionibacterium freudenreichii P23) $\bigcirc$, Lactobacillus helveticus ITGLH1; $\triangle$, Lb. helveticus ITGLH77; brined; $\triangle$, non-brined. Values are means from three trials with SD indicated by vertical bars.

\section{Evidence of free active peptidases}

The $\mathrm{NH}_{2}$ groups increased sharply in the sterile aqueous extracts of cheese obtained at day 16 and incubated at $24{ }^{\circ} \mathrm{C}$ (Fig. 5), showing the presence of active peptidases released through lysis of the starters for both LH1 and LH77 cheeses.

\section{Proteolysis}

The concentration of $\mathrm{NH}_{2}$ groups remained steady during cold room ripening, then increased sharply in the warm room and remained constant during subsequent cold storage (Fig. 6). At day 69 their concentration was higher $(+35 \%)$ in LH1 cheese than in LH77 cheese and was slightly higher $(+10 \%)$ for brined than nonbrined LH77 cheeses. The peptide profiles of aqueous cheese extracts, analysed by reversed-phase HPLC, revealed differences during ripening (results not shown). Between days 0 and 27, no changes in profiles could be detected and they were similar for both strains. At day 44, particular peaks appeared and/or varied strongly during warm room ripening. Peaks corresponding to small hydrophilic peptides and free amino acids (retention time $<15 \mathrm{~min}$ ), already detectable by day 27 , increased until the end of the ripening, sharply for LH1 cheese and moderately for LH77 cheese. Peaks corresponding to large hydrophobic peptides (retention time $>40 \mathrm{~min}$ ) were present from the beginning of ripening and increased between days 27 and 44 for both types of cheeses. Thereafter these decreased until the end of the ripening in LH1 cheese but remained almost constant for LH77 cheese.

Free amino acids were present in cheeses at very low concentrations at the end of cold room ripening and increased mainly in the warm room. Total amino acid concentrations in aqueous extract of cheeses increased during warm room ripening from 18 to $380 \mathrm{~mm}$ for LH77 and from 35 to $660 \mathrm{~mm}$ for LH1 cheeses. Qualitatively the profiles were similar for both strains, the predominant amino acids being Pro, 
Leu, Lys, Val, Gly and Glx (results not shown), in agreement with previous observations for full size Swiss cheeses (Salvat-Brunaud et al. 1995).

No significant differences could be detected between brined and non-brined cheeses either in free amino acids or chromatographic profiles (results not shown). The difference of $+10 \%$ in free $\mathrm{NH}_{2}$ groups for brined LH77 cheese compared with non-brined cheese could be attributed to activation of plasmin by salt (Fox \& Stepaniak, 1993).

\section{DISCUSSION}

Autolysis of $L b$. helveticus during the ripening of Swiss type cheese has previously been demonstrated for strain LH77; it occurred early and coincided with a drastic reduction in lactobacilli counts and the release of intracellular PepD (Valence et al. 1998). In the present study autolysis of Lb. helveticus was confirmed for this strain and compared with another industrial strain, LH1. All the results demonstrated a more extensive autolysis of LH1 compared with LH77. Indeed, the PepD signal, which is specific for lysis of Lb. helveticus, was higher for the LH1 strain. Moreover, since the LDH released must have come from Lb. helveticus or Str. thermophilus and, assuming similar behaviour of the Str. thermophilus in the two cheeses, the difference of the LDH released would reflect the greater autolysis of LH1 (5-7-fold that of LH77). This was further confirmed by comparison of the protein profiles of the aqueous extracts of the cheeses and by the release of PepD. It should be noted that the decrease in viability in the cold room (96 and $98 \%$ ) was almost identical, showing that, in the case of LH77, a significant part of the population was dead or could not be grown, but was not lysed. Hence we suggest that decrease in viability of $L b$. helveticus in cheese cannot be regarded as a reliable indicator of lysis. We also found that for both strains brining had no effect on starter viability or the extent of lysis of $L b$. helveticus, at least for small scale Swiss cheeses.

Autolysis can have an effect on proteolysis only if the peptidases released remain active in the cheese matrix. Our results demonstrated the presence of free active peptidases in cheese, in agreement with results for lactococci in Cheddar (Law et al. 1974; Wilkinson et al. 1994b) and thermophilic starters in Emmental (Gagnaire et al. 1998) cheese. The proteolysis was shown to take place mainly in the warm room, as with full size Emmental cheeses (Thierry et al. 1998). The various indices used showed greater proteolysis in LH1 cheese. The overall intracellular peptidase activity towards $\beta$-casein peptides was shown to be slightly higher for LH1 than for LH77 ( $+15 \%$; our unpublished work). Thus the greater degree of proteolysis for LH1 may be due to a more extensive lysis coupled with a slightly higher peptidase activity. However, it should be pointed out that although lysis for LH1 was 5-7-fold that of LH77, proteolysis (as measured by free amino acid content) was only $1 \cdot 8$-fold that of LH77. This suggests that there are limiting factors in Swiss cheese such as limited diffusion of the peptidases into the cheese matrix after their release and/or substrate limitation around the colonies. Moreover, even non-lysed LH77 cells could participate in the proteolysis, as suggested recently for permeating lactococci by Niven \& Mulholland (1998).

The strain dependence of autolysis has been established in vitro for lactococci and Lb. helveticus (Langsrud et al. 1987; Lortal et al. 1997), and was confirmed in cheese for lactococci (Boutrou et al. 1998; Chapot-Chartier et al. 1994; Wilkinson et al. $1994 a, b)$ and for $L b$. helveticus in the present study. There are several hypotheses to explain this strain dependence. There may be an association between the presence of a prophage and the ready lysis of a strain in cheese, and this hypothesis recently 
received experimental support for Lactococcus lactis (Lepeuple et al. 1997). Among $L b$. helveticus strains, lysogeny appears widespread : $47 \%$ of the strains are lysogenous, harbouring complete or defective prophages (Séchaud, 1990; Carminati et al. 1997). When induced by mitomycin C, the growth of LH1 and LH77 was not altered at all (Valence, 1998), suggesting that they are non-lysogenous, but this would have to be confirmed by further work. Minor variations in bacterial cell wall composition, such as the degree of peptidoglycan reticulation or $O$-acetylation, or the content of secondary polymers, may also have major effects on lysis (Logardt \& Neujahr, 1975; Niskasaari et al. 1989). Finally, differences in zymograms suggest variations in the effectiveness of autolysins between one strain and another in the same species (Valence \& Lortal, 1995). Incidentally, comparison of LH1 and LH77 autolysis in buffered solutions indicated greater autolysis for LH77, the reverse of the results obtained in cheeses. Selection of strains on the basis of their autolysis in buffered solutions may reflect only differences in autolysin efficiency or cell wall composition and not the presence of prophages, whose expression requires a growing culture. This highlights the need to develop predictive tests for lysis in Lb. helveticus species which are also able to respond to the lysogenic state of a strain.

We sincerely thank our local 'mind-mapeuse' A. Thierry for critical reading of the manuscript.

\section{REFERENCES}

Bidlingmeyer, B. A., Cohen, S. A. \& Tarvin, T. L. 1984 Rapid analysis of amino acids using pre-column derivatization. Journal of Chromatography 336 93-104

Bie, R. \& SJöströм, G. 1975 Autolytic properties of some lactic acid bacteria used in cheese production. II. Experiments with fluid substrates and cheese. Milchwissenschaft 30 739-747

Boutrou, R., Sepulchre, A., Gripon, J.-C. \& Monnet, V. 1998 Simple tests for predicting the lytic behaviour and proteolytic activity of lactococcal strains in cheese. Journal of Dairy Science 81 2321-2328

Buisson, V., KerJean, J.-R. \& Courroye, M. 1987 [Miniaturization of cheese technology.] Technique Laitière \& Marketing no. 1024 17-18, 20-23

Carminati, D., Mazzucotelli, L., Giraffa, G. \& Neviani, E. 1997 Incidence of inducible bacteriophage in Lactobacillus helveticus strains isolated from natural whey starter cultures. Journal of Dairy Science $\mathbf{8 0}$ $1505-1511$

Chapot-Chartier, M. C., Deniel, C., Rousseau, M., Vassal, L. \& Gripon, J.-C. 1994 Autolysis of two different strains of Lactococcus lactis during cheese ripening. International Dairy Journal 4 251-269

Church, F. C., Porter, D. H., Catignani, G. L. \& Swaisgood, H. E. 1985 An o-phthalaldehyde spectrophotometric assay for proteinases. Analytical Biochemistry $146343-348$

Crow, V. L., Coolbear, T., Gopal, P. K., Martley, F. G., McKay, L. L. \& Riepe, H. $1995 a$ The role of autolysis of lactic acid bacteria in the ripening of cheese. International Dairy Journal 5 855-875

Crow, V. L., Coolbear, T., Holland, R., Pritchard, G. G. \& Martley, F. G. 1993 Starters as finishers: starter properties relevant to cheese ripening. International Dairy Journal $3423-460$

Crow, V. L., Martley, F. G., Coolbear, T. \& Roundhill, S. J. $1995 b$ The influence of phage-assisted lysis of Lactococcus lactis subsp. lactis ML8 on Cheddar cheese ripening. International Dairy Journal 5 451-472

El Soda, M., Macedo, A. \& Olson, N. 1991 Aminopeptidase and dipeptidylaminopeptidase activities of several cheese related microorganisms. Milchwissenschaft 46 223-226

Fox, P. F. \& McSweeney, P. L. H. 1996 Proteolysis in cheese during ripening. Food Reviews International 12 $457-509$

Fox, P. F. \& Stepaniak, L. 1993 Enzymes in cheese technology. International Dairy Journal $3509-530$

Gagnaire, V., Lortal, S. \& LÉonil, J. 1998 Free active peptidases are detected in Emmental juice extracted before ripening in the warm room. Journal of Dairy Research 65 119-128

Heiss, E. 1996 [Rapid methods for the determination of fat in cheese.] Deutsche Molkerei-Zeitung 82 67-70

International Dairy Federation 1982 Cheese and Processed Cheese. Determination of the total solids content (reference method). Brussels IDF (FIL-IDF Standard no. 4A)

International Dairy Federation 1988 Cheese and Processed Cheese Products. Determination of chloride content. Potentiometric method. Brussels IDF (FIL-IDF Standard no. 88A)

Isolini, D., Grand, M. \& GLäTTLI, H. 1990 [Selective media for enumeration of obligatory and facultative heterofermentative lactobacilli.] Schweizerische Milchwissenschaft und Forschung $1957-59$

LaеммLI, U. K. 1970 Cleavage of structural proteins during the assembly of the head of the bacteriophage T4. Nature 227 680-685 
Langsrud, T, Landaas, A. \& Castberg, H. B. 1987 Autolytic properties of different strains of group N streptococci. Milchwissenschaft $42556-560$

Law, B. A., Sharpe, M. E. \& Reiter, B. 1974 The release of intracellular peptidase from starter streptococci during Cheddar cheese ripening. Journal of Dairy Research 41 137-146

Lepeuple, A.-S., van Gemert, E. \& Chapot-Chartier, M.-P. 1997 Analysis of the bacteriolytic enzymes of the autolytic Lactococcus lactis subsp. cremoris strain AM2 by renaturing polyacrylamide gel electrophoresis : identification of a prophage-encoded enzyme. Applied and Environmental Microbiology $644142-4148$

Logardt, I.-M. \& NeuJahr, H. Y. 1975 Lysis of modified walls from Lactobacillus fermentum. Journal of Bacteriology $12473-77$

Lortal, S., Lemée, R. \& Valence, F. 1997 Autolysis of thermophilic lactobacilli and dairy propionibacteria: a review. Lait $77133-150$

Lortal, S., Rousseau, M., Boyaval, P. \& van Heijenoort, J. 1991 Cell wall and autolytic system of Lactobacillus helveticus ATCC 12046. Journal of General Microbiology 137 549-559

Malik, A. C., Reinbold, G. W. \& Vedamuthu, E. R. 1968 An evalution of the taxonomy of Propionibacterium. Canadian Journal Microbiology 14 1185-1191

NiskasaARI, K. 1989 Characteristics of the autolysis of variants of Lactococcus lactis subsp. cremoris. Journal of Dairy Research $56639-649$

Niven, G. W. \& Mulholland, F. 1998 Cell membrane integrity and lysis in Lactococcus lactis: the detection of a population of permeable cells in post-logarithmic phase cultures. Journal of Applied Microbiology $\mathbf{8 4}$ $90-96$

O’Donovan, C. M., Wilkinson, M. G., Guinee, T. P. \& Fox, P. F. 1996 An investigation of the autolytic properties of three lactococcal strains during cheese ripening. International Dairy Journal 6 1149-1165

Онмгу , K. \& Sato, Y. 1970 Studies on the proteolytic action of dairy lactic acid bacteria. X. Autolysis of lactic acid bacterial cells in aseptic rennet curd. Agricultural and Biological Chemistry $34457-463$

Salvat-Brunaud, D., Maubois, J.-L., le Grä̈t, Y., Piot, M., Maillard, M.-B., Corre, C. \& Thierry, A. 1995 [Extraction and composition of the aqueous phase of Emmental during ripening.] Lait 75 239-249

SÉchaud, L. 1990 [Characterization of 35 Bacteriophages from Lactobacillus helveticus.] PhD dissertation, Université Paris VIII et XI

Steffen, C., Eberhard, P., Bosset, J. O. \& Rüzgg, M. 1993 Swiss-type varieties. In Cheese: Chemistry, Physics and Microbiology, vol. 2, Major cheese groups, pp. 83-110 (Ed. P. F. Fox). London: Chapman \& Hall

Thierry, A., Salvat-Brunaud, D., Madec, M. N., Michel, F. \& Maubois, J.-L. 1998 [Swiss cheese ripening: dynamics of bacterial populations and changes in composition of the aqueous phase in three industrial cheeses.] Lait 78 521-542

Thomas, T. D. 1975 Tagatose-1,6-diphosphate activation of lactate dehydrogenase from Streptococcus cremoris. Biochemical and Biophysical Research Communications 63 1035-1042

VALENCE, F. 1998 [Evidence of Lactobacillus helveticus and Propionibacterium freudenreichii autolysis in Emmental cheese. Characterization of Lb. helveticus ISLC5 autolysins.] PhD dissertation, Université Rennes I

Valence, F. \& Lortal, S. 1995 Zymogram and preliminary characterization of Lactobacillus helveticus autolysins. Applied and Environmental Microbiology $613391-3399$

Valence, F., Richoux, R., Thierry, A., Palva, A. \& Lortal, S. 1998 Autolysis of Lactobacillus helveticus and Propionibacterium freudenreichii in Swiss cheeses: first evidence by using species-specific lysis markers. Journal of Dairy Research 65 609-620

Vegarud, G., Castberg, H. B. \& Langsrud, T. 1983 Autolysis of group N streptococci. Effects of media composition modifications and temperature. Journal of Dairy Science 66 2294-2302

Wilkinson, M. G., Guinee, T. P. \& Fox, P. F. $1994 a$ Factors which may influence the determination of autolysis of starter bacteria during Cheddar cheese ripening. International Dairy Journal 4 141-160

Wilkinson, M. G., Guinee, T. P., O’Callaghan, D. M. \& Fox, P. F. $1994 b$ Autolysis and proteolysis in different strains of starter bacteria during Cheddar cheese ripening. Journal of Dairy Research 61 $249-262$

YabU, K. \& Kaneda, S. 1995 Salt-induced cell lysis of Staphylococcus aureus. Current Microbiology 30 299-303 